\title{
KARAKTERISASI XRD DAN SEM PADA MATERIAL NANOPARTIKEL SERTA PERAN MATERIAL NANOPARTIKEL DALAM DRUG DELIVERY SYSTEM
}

\author{
${ }^{1}$ Iin Lidia Putama Mursal \\ ${ }^{1}$ Prodi Farmasi Fakultas Teknologi dan Ilmu Komputer Universitas Buana Perjuangan \\ Karawang \\ iin.lidia@ubpkarawang.ac.id
}

\begin{abstract}
Abstrak
Material nanopartikel merupakan merupakan material dengan ukuran partikel berukuran 10-100 $\mathrm{nm}$. Nanopartikel dapat dibuat dengan beberapa metode yang diklasifikasikan menjadi dua jenis pendekatan yaitu dengan cara top down dan bottom up. Karakterisasi nanopartikel dapat dilakukan dengan menggunakan teknik X-Ray diffraction (XRD) dan Scanning Elekctron Microscopy (SEM). XRD sangat berguna untuk mempelajari struktur kristal, komposisi kimia, dan sifat sifat fisika dari nanomaterial. SEM merupakan teknik karakterisasi material yang banyak digunakan untuk melihat morgfologi permukaan dan ukuran butir nanomaterial. Beberapa waktu belakangan perhatian mengenai naopartikel ini telah diarahkan juga pada aplikasi di bidang farmasi khususnya dalam dalam bidang Drug Delivery System
\end{abstract}

Kata kunci: Nanopartikel, X-Ray diffraction, Scanning Elekctron Microscopy

\begin{abstract}
Nanoparticles are defined as material with a particle size in the range of 10-100 $\mathrm{nm}$. Nanomaterial fabrication methods can be classified according to whether their assembly followed either the so called top down and bottom up approach. Characterization of nanoparticles can use X-Ray diffraction (XRD) and Scanning Electron Microscopy (SEM) techniques. XRD are a very useful characterization tool to study the crystallographic structure, chemical composition and physical properties of nanomaterials. SEM is a popular technique for imaging the surfaces of almost any material grain size of nanomaterial. Recently, attention of nanomaterial has been geared towards its pharmaceutical application, especially in the area of drug delivery.
\end{abstract}

Keywords: Nanoparticles, X-Ray diffraction, Scanning Elekctron Microscopy 


\section{PENDAHULUAN}

Material nanopartikel saat ini menjadi perhatian bagi para peneliti, karena sifat fisika, mekanik dan kimia dari suatu material yang dikembangkan dalam skala nano dapat meningkat tanpa harus merusak struktur atomnya. Material nanopartikel juga memiliki cakupan aplikasi yang luas. Oleh sebab itu penelitian-penelitian mengenai nanopartikel semakin banyak dilakukan karena merupakan peluang potensial untuk menghasilkan berbagai produk yang lebih baik. Nanopartikel merupakan bahan berukuran nanometer 10-100 nm (P.Velavan et al, 2015). Material nanopartikel yang telah disintesis dapat dikarakerisasi dengan beberapa cara, beberapa cara tersebut antara lain dengan menggunakan X-Ray Difractometer (XRD) dan Scanning Electron Microscopy (SEM).

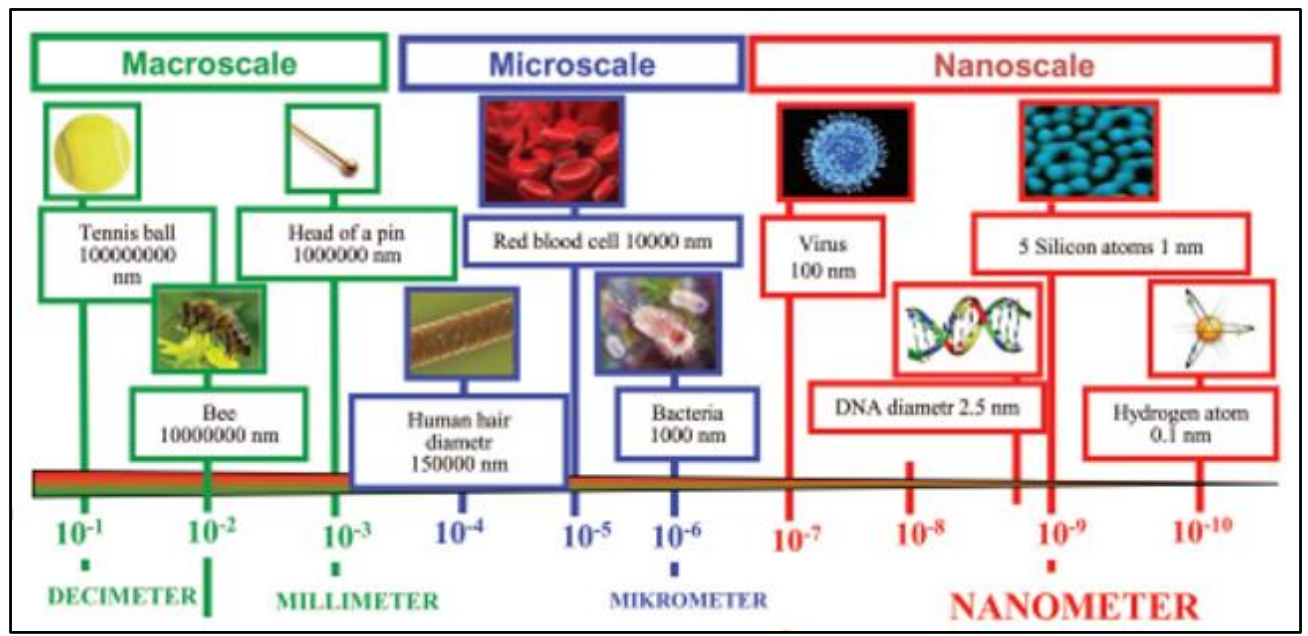

Gambar 1. Ukuran relatif skala nanopartikel dibandingkan dengan beberapa benda.

Material dalam ukuran nano memiliki keunggulan dibandingkan dengan material yang sama dalam ukuran yang lebih besar (bulk). Ukuran yang sangat kecil ini memungkinkan suatu materi memiliki sifat dan fungsi baru serta mampu mengontrol materi pada skala atom. Semakin kecil ukuran suatu partikel maka luas permukaannya akan semakin luas. Luas pemukaan yang luas ini akan menyebabkan material menjadi lebih reaktif. Keunggulan material dalam skala nanometer ini menyebabkan material nanopartikel banyak di aplikasi dalam berbagai bidang seperti dalam bidang fisika, mekanik, elektrik, kimia, dan biologi dan beberapa waktu belakangan perhatian mengenai naopartikel ini telah diarahkan juga pada aplikasi di bidang farmasi khususnya dalam dalam Drug Delivery System (Emeje et al, 2012). Ukurannya yang kecil membuat material ini mampu menembus ruang antar sel (Buzea et al., 2007) dan peningkatan afinitas dari sistem karena peningkatan luas permukaan kontak (Kawashima, 2000). 


\section{METODE SISNTESIS NANOPARTIKEL}

Terdapat banyak metode dalam mensintesis nanopartikel. Metode-metode sintesis nanopartikel tersebut dapat dikelompokkan menjadi dua pendekatan yaitu yang dengan pendekatan top down dan bottom up. pendekatan top down dilakukan dengan cara menghancurkan material asal yang masih dalam ukuran bulk menjadi skala nanometer. Contoh metode sintesis menggunakan cara top down ini antara lain ball milling yaitu dengan cara penggilingan yang memanfaaatkan energi kinetik yang dtransfer ke material berukuran bulk untuk memcahkan dan mengurangi ukuran material tersebut (Arole, 2014). Contoh metode lainnya adalah metode litografi yang dapat mengahsilkan feature nanopartikel dengan cukup baik meskipun kelemhan metode ini adalah membutuhkan energy yang cukup intesifis dan peralatan yang mahal.

Selanjutnya untuk sintesis nanopartikel dengan pendekatan bottom up adalah nanopartikel disintesis dengan cara menyusun atom-atom hingga mencapai skala nanometer. contoh metode yang menggunkaan cara bottom up ini antara lain Metal Organic Chemical Vapor Deposition (MOVCD) ( Moravec, 2011), spin coating (Nadeak, 2012). Selain metodemetode tersebut, terdapat juga metode elektrodeposisi yang direkomendasikan untuk sintesis nanokristal menurut Karappuchamy (2012), metode ini dapat menghasilkan lapisan tipis $\mathrm{TiO}_{2}$ dalam area substrat yang lebih luas kelebihan dari metode elektrodeposisi ini antara lain mudah dilakukan, biaya yang rendah, substrat dapat terlapisi pada area yang luas, dan rata-rata kemungkian terdeposisi yang tinggi.

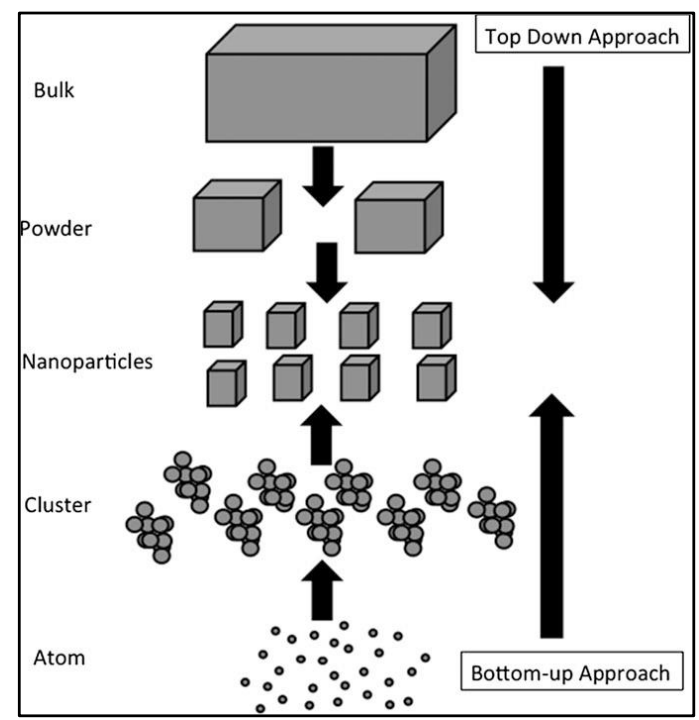

Gambar 2. Dua Jenis Pendekatan dalam fabrikasi nanopartikel: Top-Down dan Bottom-up 


\section{KARAKTERISASI NANOPARTIKEL MENGGUNAKAN XRD DAN SEM.}

\section{XRD (X-Ray Difractometer)}

Spektroskopi difraksi sinar-X (X-ray difraction/XRD) merupakan salah satu metoda karakterisasi material paling sering digunakan hingga sekarang. Teknik ini digunakan untuk mengidentifikasi fasa kristalin dalam material dengan cara menentukan parameter struktur kisi serta untuk mendapatkan ukuran partikel dari nanokristal. XRD sangat berguna untuk mempelajari struktur kristal, komposisi kimia, dan sifat sifat fisika dari nanomaterial (Sharma et al, 2012). Difraksi sinar-X terjadi pada hamburan elastis foton-foton sinar-X oleh atom dalam sebuah kisi periodik. Hamburan monokromatis sinar- $X$ dalam fasa tersebut memberikan interferensi yang konstruktif. Dasar dari penggunaan difraksi sinar-X untuk mempelajari kisi kristal adalah berdasarkan persamaan Bragg :

$$
\text { n. } \lambda=2 \cdot d \cdot \sin \theta ; \mathrm{n}=1,2, \ldots
$$

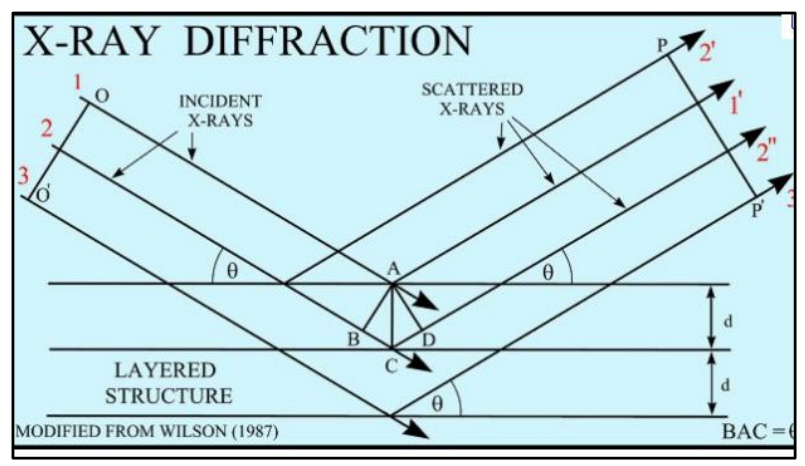

Gambar 3. Difraksi Sinar-X oleh bidang nanokristal

Dengan $\lambda$ adalah panjang gelombang sinar-X yang digunakan, $d$ adalah jarak antara dua bidang kisi, $\theta$ adalah sudut antara sinar datang dengan bidang normal, dan $\mathrm{n}$ adalah bilangan bulat yang disebut sebagai orde pembiasan. Hukum Bragg merupakan rumusan matematika tentang persyaratan yang harus dipenuhi agar berkas sinar-X yang dihamburkan tersebut merupakan berkas difraksi. Berkas sinar-X monokromatik yang datang pada permukaan kristal akan dipantulkan, dan pantulan terjadi hanya jika sudut datangnya mempunyai sudut tertentu.

Hukum Bragg merupakan rumusan matematika tentang persyaratan yang harus dipenuhi agar berkas sinar-X yang dihamburkan tersebut merupakan berkas difraksi. Berkas sinar-X monokromatik yang datang pada permukaan kristal akan dipantulkan, dan pantulan terjadi hanya jika sudut datangnya mempunyai sudut tertentu.

Berdasarkan persamaan Bragg, jika seberkas sinar-X di jatuhkan pada sampel kristal, maka bidang kristal itu akan membiaskan sinar-X yang memiliki panjang gelombang sama dengan jarak antar kisi dalam kristal tersebut. Sinar yang dibiaskan akan ditangkap oleh 
detektor kemudian diterjemahkan sebagai sebuah puncak difraksi. Makin banyak bidang kristal yang terdapat dalam sampel, makin kuat intensitas pembiasan yang dihasilkannya. Tiap puncak yang muncul pada pola XRD mewakili satu bidang kristal yang memiliki orientasi tertentu dalam sumbu tiga dimensi.

Puncak-puncak yang didapatkan dari data pengukuran ini kemudian dicocokkan dengan standar difraksi sinar-X untuk hampir semua jenis material. Keuntungan utama penggunaan sinar-X dalam karakterisasi material adalah kemampuan penetrasinya, sebab sinar-X memiliki energi sangat tinggi akibat panjang gelombangnya yang pendek. Sinar-X adalah gelombang elektromagnetik dengan panjang gelombang 0,5-2,0 mikron. Sinar ini dihasilkan dari penembakan logam dengan elektron berenergi tinggi.

Elektron itu mengalami perlambatan saat masuk ke dalam logam dan menyebabkan elektron pada kulit atom logam tersebut terpental membentuk kekosongan. Elektron dengan energi yang lebih tinggi masuk ke tempat kosong dengan memancarkan kelebihan energinya sebagai foton sinar-X. Alat yang digunakan pada difraksi sinar $\mathrm{X}$ dinamakan dengan difraktometer sinar X. Sampel diletakkan pada sampel holder difraktometer sinar X. Proses difraksi sinar X dimulai dengan menyalakan difraktometer sehingga diperoleh hasil difraksi berupa difraktogram yang menyatakan hubungan antara sudut difraksi $2 \theta$ dengan intensitas sinar X yang dipantulkan.

\section{SEM (Scanning Electron Microscopy)}

Scanning Electron Microscopy (SEM) merupakan teknik karakterisasi material yang banyak digunakan untuk melihat morgfologi permukaan partikel sampai pada ukuran $1 \mathrm{~nm}$ (Charurvedi et al, 2012). SEM adalah suatu metode yang digunakan untuk meneliti bentuk maupun struktur mikro permukaan dari suatu objek yang tidak bisa dilihat oleh mata atau mikroskop optik dengan menggunakan mikroskop elektron (Jores K et al, 2004) Rentang pembesarannya yang besar dan gambarnya dalam 3 dimensi membuat hasil karakterisasi sampel dengan menggunakan SEM ini menjadi lebih mudah untuk diamati dan dianalisa. 


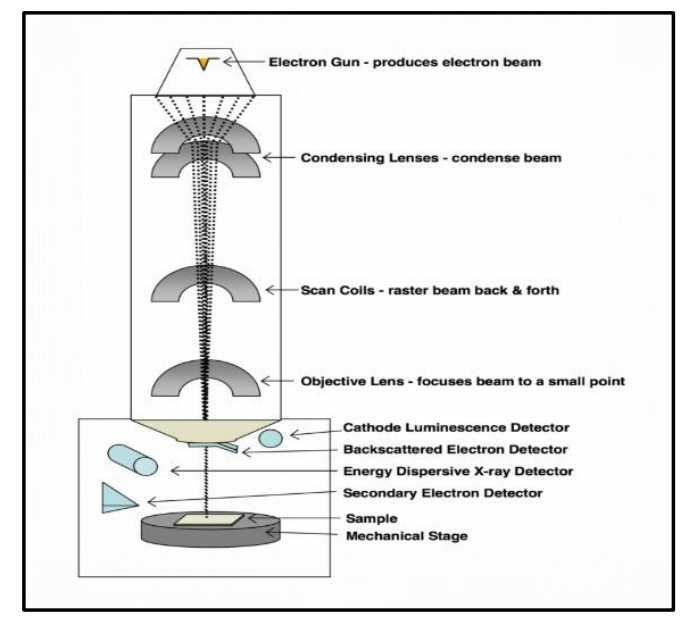

Gambar 4. Skema SEM

SEM digunakan untuk mengamati batas butir, distribusi, batas fase, bukti adanya deformasi mekanik dan komposisi kimia yang memiliki perbesaran 200.000 kali untuk mengamati ketebalan dari $200 \AA$ sampai $0,5 \mu \mathrm{m}$. Gambar 5 berikut memperlihatkan contoh hasil karakterisasi partikel menggunakan SEM yang memperlihatkan bentuk morofologi permukaan lapisan tipis $\mathrm{TiO}_{2}$ (Mursal, 2017)

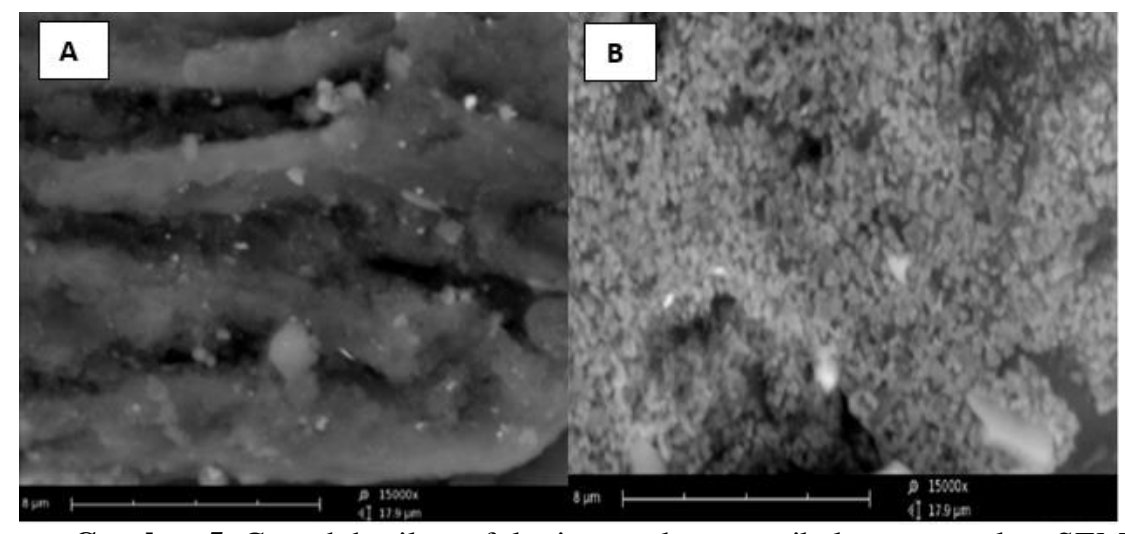

Gambar 5. Contoh hasil morfologi permukaan partikel menggunakan SEM

\section{APLIKASI NANOPARTIKEL DALAM DRUG DELIVERY SISTEM}

Keunggulan nanopartikel menjadikan material ini potensial untuk diaplikasan ke dalam berbagai bidang salah satunya adalah dalam sistem penghantaran obat (drug delivery system). Berikut beberapa contoh aplikasi nanopartikel untuk drug delivery system:

1. Material kitosan yang dikonversi dalam skala nanometer dapat diaplikasikan sebagai sistem pengahantaran insulin secara oral dimana nanopartikel kitosan dipreparasi dengan metoda gelasi ionik menggunakan tripolifosfat sebagai crosslinker agar 
mendapatkan kondisi preparasi yang dapat menghasilkan partikel berukuran di bawah $100 \mathrm{~nm}$ (Mardliyati at al, 2012).

2. Nanopartikel kitosan sebagai penghantar obat dapat dilakukan dengan pemberian secara parenteral, peroral, okular; sebagai vektor penghantar gen non-viral, penghantar vaksin, dan terapi fotodinamik (Irianto, 2011)

3. Penggunaan nanopartikel juga dapat meningkatkan utilitas dari obat dan mengurangi efek samping dari obat tersebut (Illum, 2007).

4. Nanoliposom dapat dimanfaatkan sebagai perlindungan terhadap obat dari degradasi biologis sebelum sampai pada tempat yang diharapkan (Martien, 2012)

\section{PENUTUP}

Perkembangan teknologi dan keunggulan yang dimiliki oleh nanopartikel menjadikan material ini memiliki potensi yang sangat potensial untuk diaplikasikan dalam berbagai bidang. Aplikasi nanopartikel dalam bidang salah satunya adalah di bidang kesehatan khususnya sebagai drug delivery system (sistem penghantaran obat). Pengkajian lebih lanjut mengenai nanopartikel dalam drug delivery system perlu dilakukan agar pengaplikasiannya tidak hanya dalam skala laboratorium tetapi dapat semakin dikembangkan dan diperbanyak dalam skala industri

\section{DAFTAR PUSTAKA}

Arole and S.V. Munde. 2014, Fabrication of Nanomaterials by Top-Down and Bottom-up Approaches - An Overview, Journal Of Advances in Applied Sciences and Technology

Buzea, C., Blandino, I.I.P., dan Robbie, K., 2007, Nanomaterial and nanoparticles: sources and toxicity, Biointerphases, 2: MR170-MR172

Illum, (2007). Nanoparticulate systems for nasal delivery of drugs: a real improvement over simple systems J. Pharm. Sci. 96 473-483.

Charurvedi and P. Dave. 2012, Microscopy in Nanotechnology, Formatex, 946-952

Irianto, Muljanah. 2011, Proses dan Aplikasi Nanopartikel Kitosan sebagai Penghantar Obat, Squalen Vol. 6 No. 1 Mei 2011

Jores K, Mehnert W, Drecusler M, Bunyes H, Johan C, MAder K. Investigation on the stricter of solid lipid nanopartuicles and oil-loaded solid nanoparticles by photon correlation spectroscopy, field flow fractionasition and transmission electron microscopy. J Control Release. 2004;17:217-27.

Karappuchany, 2012, preparation of nanosrtructured TiO2 photoelectrode for flexible dye sensitized solar cell application. Apply Nanosci.DOI 10.1007/s13204-012-0140-6 
Kawashima, Y., Yamamoto, H., Takeuchi, H., And Kuno, Y., 2000, Mucoadhesive DL lactide/glycolide copolymer nanospheres coated with chitosan to improve oral delivery of elcatonin, Pharmaceutical Development and Technology, 5(1): 77- 85

Misra S, 2015, Titania Nanocrystals as Active Host for Safe Drug Delivery, Applied Science and Advanced Materials International Vol. 1 (6), July 2015, pp. 169-170).

Marliyanti et al. 2012, Preparasi Dan Aplikasi Nanopartikel Kitosan Sebagai Sistem Penghantaran Insulin Secara Oral, Prosiding InsiNas 2012, MT 25- MT 30

Martien, R., Adhyatmika, Irianto, Iramie D. K.,Farida, V., Sari, Dian Purwita. 2012. Perkembangan Teknologi Nanopartikel Sebagai Sistem Penghantaran Obat. Majalah Farmasetik, Vol. 8 No. 1 Tahun 2012.

M.O.Emeje, I.C Obidike, E.I Akpabio and S.I Ofoefule. 2012, Nanotecnology in Drug Delivery, Intech, 69-106

Mursal. 2017, Pengaruh Penambahan Asam Borat $\left(\mathrm{H}_{3} \mathrm{BO}_{3}\right)$ Terhadap Hasil Karakterisasi Nanokristal TiO 2 , PharmaXplore, Vol. 1 No 2 November 2016

Moravec et al. 2011, NiOx Nanoparticle Synthesis by Chemical Vapor Deposition from Nickel Acetylacetonate, Material Sciences and Applications, 2011, 2 258-264

Nadeak. 2012, Variasi Temperatur dan Waktu Tahan Kalsinasi terhadap Unjuk Kerja Semikonduktor TiO2 sebagai Dye Sensitized Solar Cell (DSSC)dengan Dye dari Ekstrak Buah Naga Merah. Jurnal Teknik ITS Vol 1, (Sept, 2012) ISSN: 2301-9271

P. Velavan, C.Karuppusamy dan P. Venkatesen. 2015, Nanoparticles as Drug Delivery Systems, Journal of Pharmaceutical Sciences and Research,Vol. 7(12), 2015, 1118-1122.

R.Sharma, D.P. Bisen, Shukia and B.G. Sharma. 2012, X-Ray Diffraction : A Powerful Method of Characterizing Nanomaterials, Recent Research in Science and Technology, 4(8) : 7779 